\title{
Potentials and Constraints of Small-Scale Livestock Productions in Cambodia
}

\author{
Siek Darith1,2, Shiwei Xu1 ${ }^{*}$, Wen Yu' ${ }^{1}$, Ahmed Abdul-Gafar1', Sa Kennvidy3, Ou Ratanak ${ }^{3}$, \\ Eric Mukeba Mbala1 \\ ${ }^{1}$ Agricultural Information Institute, Chinese Academy of Agricultural Sciences, Beijing, China \\ ${ }^{2}$ Regional Polytechnic Institute TechoSen Battambang, Ministry of Labor and Vocational Training, Battambang, Cambodia \\ ${ }^{3}$ Graduate School of Agricultural Science, Royal University of Agriculture, Phnom Penh, Cambodia \\ Email: darith9398@yahoo.com, ‘xushiwei@caas.cn,yuwen@caas.cn,abd.gafar1@icloud.com,kennvidy@yahoo.com
}

How to cite this paper: Darith, S., Xu, S.W., Yu, W., Abdul-Gafar, A., Kennvidy, S., Ratanak, O. and Mbala, E.M. (2017) Potentials and Constraints of Small-Scale Livestock Productions in Cambodia. World Journal of Engineering and Technology, 5, 15-22.

https://doi.org/10.4236/wjet.2017.52B002

Received: April 28, 2017

Accepted: June 26, 2017

Published: June 29, 2017

\begin{abstract}
Livestock husbandry plays a very important role in rural areas of Cambodia. Farmers mostly have complained about the declining revenue from livestock production which supports their livelihood. Therefore, the study aimed at investigating the potentials and constraints of smallholder livestock productions in Battambang province. Primary and secondary data were collected to meet the objectives. Data were collected interviewing 204 households. Some of the advantages of the Cambodia livestock subsector are the increasing market demand: increasing domestic market for livestock and increasing demand from neighboring countries (especially cattle); the rich source of manure and other agricultural input such as transportation means, ploughing etc. More so, there is high expectation of the farmers experiencing increase in production since more supports are provided by both governmental and non-governmental organizations. On the other hand, the subsector witnesses some constraints including the low level of education of the livestock farmers, erratic market prices as a result of too many middlemen, local breed with low productivity and traditional management system still dominates the subsector. Scarcity of abled labor and seasonal cost is also one of the factors impeding the subsector to reaching it potential. This study suggests that to reach full potential in the livestock sector of Battambang of Cambodia, the government needs to address the infrastructural problems and private sector needs to be encouraged to invest in the sector in livestock input industries.
\end{abstract}

\section{Keywords}

Potential, Constraints, Livestock Production, Battambang, Cambodia

\section{Introduction}

The livestock sector is fundamental to global nutrition and food security, and 
serves as a major source of cash income and delivers important products and services such as asset saving, traction, manure for fuel and fertilizers and fiber. The demand for livestock products projected to grow about $70 \%$ in the year 2050 , to be driven by growing world population, increasing affluence, and urbanization [1]. In developing countries, the total consumption of meat is projected to expand to around $48 \mathrm{Mt}$ by 2025 which will account for approximately $73 \%$ of the additional output [2]. In Cambodia, with an estimated annual human population growth rate of $1.8 \%$, the livestock subsector projected increase in meat demand to about 274,479 to 328,085 tons/year from 2014 to 2024 . The projection for pig annual demand is 3.25 million heads compared to the annual demand in 2.7 million heads in 2014. The current broiler demand is around 800,000 - 1,000,000 birds per month [3]. All these evolving developments will have considerable alignment to the future demand and supply pattern of the livestock subsector of Cambodia [4]. The rise in demand for livestock products will provide a significant economic opportunity for livestock farmers in developing countries and may provide a way for them to escape poverty.

However, most livestock in Cambodia are raised under a subsistence production system, with a few small commercial cattle (beef and dairy), pig and chicken farms. Cambodian farmers raise animals traditionally following their cultural heritage. Shortage knowledge in livestock husbandry and inadequate institution and infrastructures results in low productivity and widespread of disease (in border and trans-boundary diseases), parasitism and poor nutrition [3] [5] [6] [7]. Base on the current trend, the growth rate of livestock production for the next few years remains moderate. This is being achieved under a system in which production inputs are minimal. There is clearly considerable scope for improving production and farming development efficiency and increasing output even within the existing low input system. Therefore, the present study aimed at investigating the potentials and constraints of smallholder livestock productions in Battambang province. This study is expected to provide guidelines to set up appropriate strategies for future developments of the livestock production in Cambodia and to reveal the main obstacles on livestock production as a whole.

\section{Methodology}

The main methods presented in this paper were based on qualitative and quantitative primary data. 204 prepared questionnaires were distributed among staff to interview the small-scale household farmers in six selected district of Battambang province of Cambodia (see Table 1). Informal conversation and direct observation was preliminary used to better understand the target area, living condition, and the existing livestock variety (cattle pig and chicken). All data from the research were entered into EpiData software for coding and classification of variables. The knowledge gained in the interviews was used in a SWOT (Strengths, Weaknesses, Opportunities and Threats) analysis to formulate options for the future guidelines to the development of the subsector. 
Table 1. The sample distribution in each locality of Cambodia household.

\begin{tabular}{cccccccccc}
\hline \multirow{2}{*}{ Districts } & \multicolumn{3}{c}{ Simpling Size Selection } & \multicolumn{2}{c}{ Cattle } & \multicolumn{2}{c}{ Pig } & \multicolumn{2}{c}{ Chicken } \\
\cline { 2 - 9 } & $\begin{array}{c}\text { No. of } \\
\text { Village }\end{array}$ & $\begin{array}{c}\text { H. H } \\
\text { Sample }\end{array}$ & $\%$ & Sample & $\begin{array}{c}\text { Death } \\
\text { rate (\%) }\end{array}$ & Sample & $\begin{array}{c}\text { Death } \\
\text { rate (\%) }\end{array}$ & Sample & $\begin{array}{c}\text { Death } \\
\text { rate (\%) }\end{array}$ \\
\hline Aek Phnum & 3 & 39 & 19 & 39 & 2.9 & 3 & 0 & 20 & 22.1 \\
Banan & 3 & 31 & 15 & 30 & 1.8 & 6 & 18 & 24 & 26.8 \\
Moung Ruessei & 3 & 37 & 18 & 37 & 2.5 & 6 & 15 & 23 & 17.0 \\
Ratanak Mondol & 2 & 20 & 10 & 20 & 1.0 & 2 & 3.1 & 16 & 21.3 \\
Sangkae & 4 & 47 & 23 & 44 & 3.5 & 4 & 8.3 & 23 & 19.1 \\
Thma Koul & 3 & 30 & 15 & 27 & 1.5 & 7 & 0 & 26 & 28.7 \\
Total & 18 & 204 & 100 & 197 & 2.4 & 28 & 8.5 & 132 & 22.2 \\
\hline
\end{tabular}

\section{Result and Discussion}

\subsection{Perspective of Farmer in the Last Five Years}

The farmers were asked to compare the head count of their present livestock and that of five years back, Figure 1 depicts the changes in the livestock head count. As shown in the figure, livestock production has increased considerable as 57\% of the farmers reported to have had increase in the head count of their livestock in the region. $13 \%$ of the farmers experienced a decrease and $30 \%$ reported to have relatively the same head count to that of five years back.

To further support these, the farmers were asked to provide causal reasons for these changes. The farmers who experienced increase, they explained that one of the reasons encouraging them to increase the head count of their livestock was the readiness of demand of their livestock in the market at a favorable price. Other reasons provided include the awareness of government and Government and Non-Governmental Organization supports on vaccinations, de-worming and disease treatments; the relatively stable reproduction of their new breed livestock during that period; and more so, the rethinking and consideration of livestock production as a form of investment and not food alone.

However, the $13 \%$ of the farmers that reduced experienced reduction in their livestock head count have different views to the reason why the reduction occurred. They complained that the high death rate of their livestock especially from diseases (chicken and pig) discourages them to invest more into the livestock farming. Among other reasons include the high cost of inputs such as concentrated feed for pig and chicken; an unfavorable market prices; diminishing labor forces; and insufficient grasses due to limited land space for grassland. As for the labor force, majority of the farmers had their children taking care of the larger livestock but as these children go to school or finds jobs in other regions or the neighboring countries, the farmers are left with no choice but to cut down the number of livestock to increase optimal production. Another reason provide by the farmers was the insufficient capital to maintain or increase the stock of their livestock.

As for the $30 \%$ of the farmers which maintained the production scale of their 


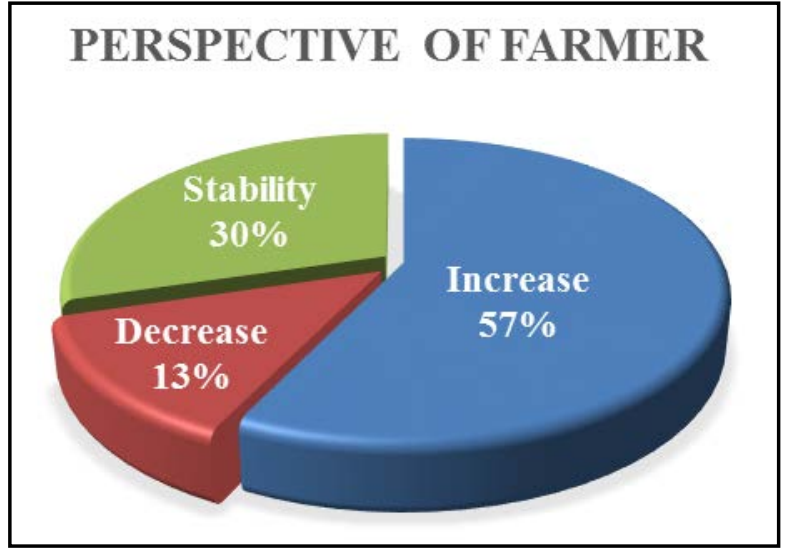

Figure 1. Perspective of farmer.

livestock, majority of them are satisfied with the level of production and do not wish to increase or reduce despite the opportunities provided by the market, the government and NGOs, as well as the weakness and threats experienced. These farmers are in two categories; those that deliberately maintained the same level of production and those that natural remained in the same level of production.

\subsection{Potentials and Constraints to the Small-Scale Livestock}

The study focused habitually on livestock production in the six (6) selected district of Battambang provinces of Cambodia. The livestock play extremely imperative function for the livelihood of the rural sector in Cambodia. For instance, it generates income for the family from its sales (egg, meat and live animals), employing labor force (especially for cattle), provides organic fertilizer, and other advantages to both human and environment. Although in these six districts, livestock rearing is an important occupation, they are still incapable to formulate the livestock system with high productivity. SWOT analysis is a good method to look for how the simultaneous interaction of constraint and potential would describes the conditions in the six districts. Using semi-structure questionnaires to conduct a face to face interviewed with farmers and some key informants (local authorities, Village Veterinarians, middle man), this study classified the outcome into four categories: Strengths, Weakness, Opportunities, and Threats:

Strengths (S): Livestock farming became the consecutive animal-raising habits since the ancient. The most significant factors encouraging the farmers to raise livestock are summarized in this study. Majority of the farmers in Cambodia pass their livestock production habit (especially cattle, pig and chicken) to their next generations as heritage for new family, thus as generation to generation passes, livestock still remained in the favor of the households. Other strength observed in this study area include the diversification of livestock breeds by farmers which help them reduce to reduce risk total lose in case of outbreaks or on the demand side specific request by purchasers. Easy access to farm residues, as majority of the livestock farmers also grow crops (most rice), there is readily farm residue to feed their livestock. Other farmers that solely 
farm livestock have easy access to the crop farmers within their vicinity. Low labor costs is another strength to the livestock farming in Battambang, here, majority of the farmers hire less labor and use household labor which is much cheaper. Some of the farmers raised the livestock for income to support their livelihood. The most occurred reasons for livestock production given by the famers are the advantages of raising each specific livestock. For instance, the farmers use cattle as tool (power for ploughing), direct product (meat, milk) and indirect product (manure).

Weakness $(W)$ : Seasonal cost of resources has been one of the greatest weakness to the subsector. For instance during dry season, grassing become scare and in turn expensive, likewise the concentrated feed. Some farmers in the study area also complained of shortage of water during the dry season. The raining season, on the other hand, follows with sheltering problem of the livestock especially during flooding and during this period, disease spread easily. The low labor cost which could stand as an advantage to low production cost could also be a disadvantage as no one would want to continue working at low wage thus scarcity of labor. Another weakness of the subsector in the study area was that majority of the livestock are local breeds with low productivity.

Opportunities (O): Despite all odds, the domestic demand and international demand from neighboring countries for livestock is expanding. One of the reason for the domestic increase is increase in population while the demand for the neighboring country comes as a result of it cheapness in the country especially cattle prices. In the study area, majority of the farmers reported selling stock of their livestock to Vietnamese and customer from Thailand. In most cases, the neighboring countries come into the country to bargain then convey back to their countries. Few cases of the Battambang farmers transporting to the border of Thailand is recorded. Regional Polytechnic Institute TechoSen Battambang (RPITSB), Ministry of Labor and Vocational Training (MLVT), Ministry of Agriculture Forest and Fishery (MAFF), FAO, ADB, World Bank, and some other local projects provide the training to the farmers and provision of new animal breeds and techniques. Some of the supports of these departments and organizations include 1) providing the new breed (chicken, pig and cattle), 2) technical training of small-scale livestock production, 3) feed and animal feeding technique for extension training, 4) grasses and new species in cultivation training (for cattle), 5) agricultural diversification system training, 6) biogas training and 7) village animal worker or veterinarian for training program. Among all these, the new breed and techniques were most significant to be considered.

Threats ( $T$ ): despite the involvement of many organization and departments in the subsector, it is affected by other external factors such as social security, slow control of outbreaks, the poisons from agrochemical which not only affect the plant but the water in the environment that the livestock depend on as well. The change in climate is no short to becoming a threat to the subsector the extreme and erratic changes in temperature distorting the physics of the livestock especially chicken and pig. One other threat face in the subsector include the 
dependence on importation of vaccines and other important vet medicine and poor infrastructure in the rural regions where livestock are mostly raised. Even with the expanding market demand, the livestock market still faces constraints such as the price volatility of pig and chicken which is mostly caused by the middlemen.

The assessment of SWOT in the 6 districts of Battambang province of Cambodia aimed at finding out the rational and motivation of livestock farming as well as the constraints and opportunities, then formulate strategies for the future policies. For threats and weaknesses which are beyond the control of man, the impact of infrastructure plays a strong role to curbing the constraints.

\section{Conclusion and Recommendation}

The study uses a quantitative and qualitative survey data collected from six districts of Battambang province of Cambodia to show the potentials and constraints of livestock production in the province. The result illustrating in Table 2 below highlights meaningful areas at which the livestock subsector can be

Table 2. Assessment of SWOT by 6 districts.

\begin{tabular}{|c|c|c|}
\hline $\begin{array}{l}\text { SWOT } \\
\text { Analysis }\end{array}$ & Opportunities (O) & Threats (T) \\
\hline $\begin{array}{l}\text { Strengths } \\
\text { (S) }\end{array}$ & $\begin{array}{l}\text { Strengths-Opportunities: } \\
>\text { Livestock husbandry as a norm and heritage to next generation } \\
\text { of farmers. } \\
>\text { Diversification of livestock and livestock breeds } \\
>\text { Expanding domestic and international market } \\
>\text { Access to resources such as farm residues. } \\
>\text { Farmers willing to join with the private, NGO, and } \\
\text { governmental authorities to improve their technique and } \\
\text { capacity via training. } \\
>\text { Farmers ready to cooperate and adopt new feed composition, } \\
\text { vaccination, and new breeds. } \\
>\text { Overall, there is greater potential in the subsector given the } \\
\text { natural state and support of both private and government. }\end{array}$ & $\begin{array}{l}\text { Strengths-Threats: } \\
\text { Outbreaks: to prevent complete loose of livestock, } \\
\text { diversification of livestock and livestock breeds } \\
\text { plays great role to reducing complete loose of } \\
\text { livestock. This is one of the strength the farmers } \\
\text { possess to reducing spread of outbreaks. } \\
\text { Hash climate change: the threat of climate change } \\
\text { to livestock cannot be overemphasized } \\
\text { enough. Government will have to play greater role } \\
\text { in curbing this threat in the subsector by providing } \\
\text { basic social amenities that will support the animal } \\
\text { farms such as electricity. } \\
\text { High price volatility: price fluctuation is one of the } \\
\text { major threat faced by the rural farmers in } \\
\text { Cambodia and the middlemen mostly cause this. } \\
\text { Access to resource such as market information } \\
\text { from market board will play a great role to } \\
\text { reducing this volatility in the subsector }\end{array}$ \\
\hline $\begin{array}{c}\text { Weakness } \\
\text { (W) }\end{array}$ & $\begin{array}{l}\text { Weaknesses-Opportunities: } \\
>\text { The subsector faces seasonal high cost of production: the } \\
\text { government can use the available opportunity to provide } \\
\text { relevant infrastructures supporting subsector especially } \\
\text { during scarcity of essential inputs, market board to } \\
\text { regulate input prices etc. } \\
>\text { The local breeds of farmers: government and NGOs provides } \\
\text { cross breeds or new breeds to farmers to increase the farming } \\
\text { diversification, more so, to push farmer toward modern system } \\
\text { of livestock farming. } \\
>\quad \text { Traditional method of livestock farming: The Government, } \\
\text { NGO, and other organization should provide new/modern } \\
\text { techniques of livestock rearing for the rural farmers. }\end{array}$ & $\begin{array}{l}\text { Weaknesses-Threats: } \\
>\text { Poor infrastructure not supporting modern } \\
\text { techniques or new breeds requiring special } \\
\text { conditions. } \\
>\text { Slow control of outbreak leads to more loose } \\
\text { of livestock. Some of these slowness are caused by } \\
\text { dependence on import for essential vet medicines. } \\
>\text { With the non-existence of market board, } \\
\text { middlemen prey upon livestock farmers. } \\
>\text { Seasonal scarcity of resources especially feed, } \\
\text { labor and water in some cases. }\end{array}$ \\
\hline
\end{tabular}


improved as well as the constraints to be controlled if not eradicated. The study has significant policy implication to the development of the livestock sector in Cambodia. According to the study, some of the strength of the livestock farming in the study area includes the strong heritage of livestock farming, the diverse livestock and livestock breed present in the area and low labor cost. The opportunities include increasing market demand for livestock product, involvement of the government and NGOs to training and provision of new breeds to the farmers. On the other hand, the threat and weaknesses to the development of the subsector include seasonal cost of inputs, livestock high volatility price, effect on climate change (temperature), poor infrastructure, and import dependence of vet medicines, slow outbreak control and scarcity of labor.

For the subsector meeting its full potentials, this study suggests that government needs to address the infrastructural problems and private sector needs to be encouraged to invest in the subsector. For establishment of vet medicine industry and feed industries in the country, the research institute should focus on new breed, such resistant to biotic and abiotic constraint factors etc., provision of credit to farmers to encourage them to adopt modern methods rather than relying on cheap and unproductive traditional methods.

\section{Acknowledgements}

This paper was supported by the CAAS Science and Technology Innovation Project (number: CAAS-ASTIP-2017-AII), founded by Chinese Academy of Agricultural Sciences and Technology. We also highly appreciate Pun Robarng, Chhoep Dany, Chay Samoeurn, Son Boren, Moun Sovannara, Doeurn Va, SuoSinoeun and Din Chamroeun, the graduate student of University Management and Economic (UME) and Royal University of Agriculture (RUA) for their contribution.

\section{References}

[1] OECD/Food and Agriculture Organization of the United Nations (2014) OECDFAO Agricultural Outlook 2014, OECD Publishing.

[2] OECD/FAO (2016) "Meat", in OECD-FAO Agricultural Outlook 2016-2025, OECD Publishing, Paris.

[3] Department of Animal Health and Production (2015) Strategic Planning Framework for Livestock Development 2016-2025, Ministry of Agriculture Forestry and Fisheries, Kingdom of Cambodia. http://dahp-maff.org/blog/dahp-10-year-strategic-plan-2016-2025-eng/

[4] Khieu B. (2000) Cattle Raising as Smallholder in Cambodia, CelAgrid, Cambodia. (Khmer Version)

[5] Darith, S., Xu, S.W., Yu, W. and Abdul-Gafar, A. (2016) Optimization Model of Cattle Husbandry for Rural Household in Cambodia. Journal of Agricultural Chemistry and Environment, 5, 6-11. https://doi.org/10.4236/jacen.2016.51B002

[6] Siek, D., Xu, S.W., Yu, W., Ahmed, A.-G. and Din, C. (2016) Optimization Model of Small-Scale Chicken Production in Cambodia. Open Journal of Social Sciences, 4 , 295-299. https://doi.org/10.4236/jss.2016.45032 
[7] Weaver, J., Kamakawa, A., Stuaro, L. and Bouchot, A. (2011) PVS Gap Analysis Report, "Cambodia”, World Organisation for Animal Health, F-7517 Paris, France. http://dahp-maff.org/blog/oie-pvs-gap-analysis-report/

Submit or recommend next manuscript to SCIRP and we will provide best service for you:

Accepting pre-submission inquiries through Email, Facebook, LinkedIn, Twitter, etc. A wide selection of journals (inclusive of 9 subjects, more than 200 journals)

Providing 24-hour high-quality service

User-friendly online submission system

Fair and swift peer-review system

Efficient typesetting and proofreading procedure

Display of the result of downloads and visits, as well as the number of cited articles

Maximum dissemination of your research work

Submit your manuscript at: http://papersubmission.scirp.org/

Or contact wjet@scirp.org 